\title{
Comparison of C-reactive protein among controlled, moderately controlled and uncontrolled diabetic subjects in a Bangladeshi population
}

\author{
M Saiedullah $1 *$, MR Rahman ${ }^{1,2,}$ SS Shaha ${ }^{3}$, \\ S Begum ${ }^{1}$, S Hayat ${ }^{1}$, SM Kamaluddin ${ }^{1}$ \\ ${ }^{1}$ Department of Biochemistry and Cell Biology, Bangladesh Institute of Health Sciences, Dhaka, Bangladesh \\ ${ }^{2}$ Department of Biochemistry, Delta Medical College, Dhaka, Bangladesh \\ ${ }^{3}$ Department of Immunology, Bangladesh Institute of Health Sciences, Dhaka, Bangladesh
}

\begin{abstract}
Poor glycemic control is significantly associated with the development of macrovascular complications of diabetes. C-reactive protein (CRP) is considered as a sensitive and independent risk factor for cardiovascular events. The aim of this study was to compare elevated CRP among controlled, moderately controlled and uncontrolled diabetic subjects in a Bangladeshi population. CRP and glycosylated hemoglobin $\mathrm{A} 1 \mathrm{c}(\mathrm{HbA} 1 \mathrm{c})$ were measured in 226 confirmed diabetic subjects purposively and randomly. Elevation of CRP in the moderately controlled (relative risk 1.64, $\mathrm{P}<0.01$ ) and uncontrolled diabetic subjects (relative risk 1.8, $\mathrm{P}<0.001$ ) were significantly higher than controlled diabetic subjects. $\mathrm{HbA}_{1 \mathrm{c}}$ was significantly associated with the likelihood of elevated CRP in the moderately controlled diabetic subjects (OR:2.87, 95\% CI: 1.41 to $5.87, \mathrm{P}<0.01)$ and in the uncontrolled diabetic subjects (OR:3.83, 95\% CI: 1.94 to $7.58, \mathrm{P}<0.001)$. This study revealed that the likelihood of elevated $\mathrm{CRP}$ is associated with the increase of $\mathrm{HbA} 1 \mathrm{c}$ in diabetic subjects.
\end{abstract}

Key words: CRP, HbA1c, diabetes, cardiovascular disease

\section{Introduction}

C-reactive protein (CRP), an acute phase protein, is considered as a marker of nonspecific systemic inflammation. Most of the healthy individuals have CRP concentration $<6 \mathrm{mg} / \mathrm{L}$. It is a stronger predictor of future cardiovascular events than low-density lipoprotein cholesterol (LDL-C) (1). The co localization of CRP and LDL-C is a fundamental initializing step in cellular migration and plaque development. Once present, CRP upregulates adhesion molecule expression, activates complement, and induces monocyte tissue factor expression (2). CRP also has pro-inflammatory properties that could potentially contribute to the pathogenesis, progression and complications of atheroma $(3,4)$. Elevated CRP is associated with higher level of insulin and $\mathrm{HbA}_{1 \mathrm{c}}(5,6)$ and increased risk of later development of diabetes $(7,8)$. The base-line plasma concentration of CRP predicts the future myocardial infarction and stroke (9). Elevated CRP is also considered as an independent predictor of development of peripheral arterial disease and may provide additive information over the traditional lipid parameters (10).

Diabetes and cardiovascular complications are increasing in our country. As CRP is a predictor of both the development of diabetes and cardiovascular events, we aimed to compare CRP among controlled, moderately controlled and uncontrolled diabetic subjects in a Bangladeshi population.

\section{Methods}

This study was conducted in the Department of Biochemistry and Cell Biology and Department of Immunology, Bangladesh Institute of Health Sciences (BIHS) during January to March 2010. 
Two hundred twenty six confirmed diabetic subjects were included randomly in this study. Serum CRP was measured by a semiquantitative method (Omega Diagnostic Ltd., UK). HbA1c was measured by HPLC based method using D-10 ${ }^{\circledR}$ hemoglobin assay system (Bio-Rad, USA) in confirmed diabetic subjects. Subjects were grouped as controlled diabetic subjects $\left(\mathrm{HbA}_{1 \mathrm{c}} \mathrm{7.0 \%}\right)$, moderately controlled diabetic subjects (HbA1c: $7.1-9.0 \%$ ) and uncontrolled diabetic subjects (HbA1c > 9.0\%). Results of CRP were expressed as negative (CRP concentration $<6 \mathrm{mg} / \mathrm{L}$ ) and positive (CRP concentration $6 \mathrm{mg} / \mathrm{L}$ ) and compared by Fisher's exact test among different diabetic groups classifie $\underline{\alpha}$ according to $\mathrm{HbA1c}$ values.

\section{Results}

Mean \pm SD age of the controlled, uncontrolled and moderately controlled diabetic group were $45.6 \pm 9.2,47.74 \pm 9.65$ and $46.53 \pm 8.96$ years respectively; the differences of mean ages were not statistically significant compared by unpaired $\mathrm{t}$ test $(\mathrm{p}>0.05)$. Of the total study subjects, $51 \%$ were male and $49 \%$ were female. $32 \%$ study subjects had $\mathrm{CRP}<6 \mathrm{mg} / \mathrm{L}$ and $68 \%$ had CRP 6 $\mathrm{mg} / \mathrm{L}$. The mean $\pm \mathrm{SD}$ values of $\mathrm{HbA}_{1 \mathrm{c}}$ in the controlled, moderately controlled and uncontrolled diabetic subjects were $6.17 \pm 0.49 \%, 8.02 \pm 0.6 \%$ and $11.7 \pm 1.89 \%$ respectively $(\mathrm{P}<0.001)$. Number of study subjects with positive CRP was significantly higher among the moderately controlled diabetic subjects than controlled diabetic subjects (OR:2.87, 95\% CI: 1.41 to 5.87, $\mathrm{P}<0.01$, Figure 1) and the relative risk was 1.64 (95\% CI: 1.15 to 2.34 ). The relative risk was not statistically significant in the uncontrolled diabetic subjects than moderately controlled diabetic subjects (relative risk: 1.09, 95\% CI: 0.89 to 1.35 ; OR:1.33, 95\% CI:0.692.59, $\mathrm{P}>0.05)$. The relative risk in the uncontrolled diabetic subjects was 1.8 (95\% CI: 1.29 to 2.51 ) compared to controlled diabetic subjects and it was statistically significant (OR:3.83, 95\% CI: 1.94 to $7.58, \mathrm{P}<0.001$,

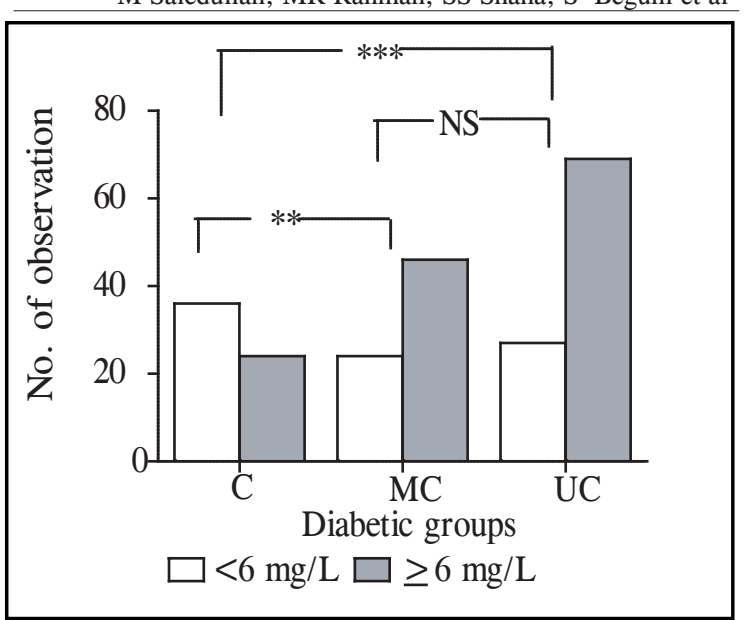

Figure 1. Comparison of CRP among controlled, moderately controlled and uncontrolled diabetic subjects. NS, not significant; **, $\mathrm{P}<0.01$; ***, $\mathrm{P}<0.001$

\section{Discussion}

This study shows that elevated serum CRP level $(\mathrm{CRP} \geq 6 \mathrm{mg} / \mathrm{L})$ was associated with higher level of $\mathrm{HbA} 1 \mathrm{c}$ in moderately controlled and uncontrolled diabetic subjects. Subjects with elevated CRP were also higher $(32 \%$ for CRP $<6 \mathrm{mg} / \mathrm{L}$ and $68 \%$ for $\mathrm{CRP} \geq 6 \mathrm{mg} / \mathrm{L}$ ) in the total study group. In a study carried out in a Bangladeshi population showed that CRP level was significantly elevated in newly diagnosed diabetic subjects than apparently healthy individuals (11) and significant positive correlation was found between LDL-C and HbA1c in established diabetic subjects (12). As elevated CRP with elevated serum LDL-C have higher mortality and morbidity than elevated LDL-C alone (1), much attention should be paid to the CRP beside the traditional risk factors (lipid profile) of cardiovoscular diseasein diabetic subjects.

In conclusion, this study demonstrated that a higher $\mathrm{HbA}_{1} \mathrm{c}$ is significantly associated with a greater likelihood of higher CRP in moderately controlled and uncontrolled diabetic subjects.

Acknowledgment: The Authors are grateful to Bio-Trade International for the partial financial support. 
Comparison of C-reactive protein among controlled, moderately

\section{References}

1. Ridker PM, Rifai N, Rose L, Buring JE, Cook NR. Comparison of C-reactive protein and low-density lipoprotein cholesterol levels in the prediction of first cardiovascular events. $\mathrm{N}$ Engl $\mathrm{J}$ Med 2002,347:1557-65.

2. Armani A, Becker RC: The biology, utilization, and attenuation of C-reactive protein in cardiovascular disease. Part II. Am Heart J 2005;149:977-983

3. Pepys MB. C-reactive protein fifty years on. Lancet 1981;i:653-6.

4. Lagrand WK, Visser CA, Hermens WT, Niessen HWM, Verheugt FWA, Wolbink G-J, Hack CE. Creactive protein as a cardiovascular risk factor. More than an epiphenomenon? Circulation 1999; 100:96102.

5. Wu T, Dorn JP, Donahue RP, Sempos CT, Trevisan M. Association of serum C-reactive protein with fasting insulin, glucose and glycosylated hemoglobin. Am J Epidemiol 2002;155:65-71

6. King DE, Mainus AG, Buchanan TA, Pearson WS. C-reactive protein and glycemic control in adults with diabetes. Diabetes Care 2003;26:1535-9

7. Pradhan AD, Manson JE, Rifai N, Buring JE, Ridker PM. C-reactive protein, interleukin-6, and risk of developing type 2 diabetes mellitus. JAMA;2001:286:327-334
8. Barzilay JI, Abraham L, Heckbert SR, Cushman M, Kuller LH, Resnick HE, Tracy RP. The relation of markers of inflammation to the development of glucose disorders in the elderly: the Cardiovascular Health Study. Diabetes 2001;50:2384-9

9. Ridker PM, Cushman M, Stampfer MJ, Tracy RP, Hennekens $\mathrm{CH}$. Inflammation, aspirin, and the risk of cardiovascular disease in apparently healthy men. N Engl J Med 1997;336:973-9.

10. Ridker PM, Stampfer MJ, Rifai N. Novel Risk Factors for Systemic Atherosclerosis: A Comparison of C-Reactive Protein, Fibrinogen, Homocysteine, Lipoprotein(a), and Standard Cholesterol Screening as Predictors of Peripheral Arterial Disease. JAMA 2001;285:2481-2485

11. Rahman MM, Kamal AHM, Mollah FH, Hafiz MG, Arslan MI. Association of C-reactive Protein with Fasting Blood Glucose in Newly Diagnosed Type 2 Diabetes Mellitus Patients. Bangladesh J Pathol 2009;24(2):4-7

12. Saiedullah M, Sarkar A, Hayat S, Ahmad A, Rahman MR, Rahman MT, Mumu MA. Comparison of lipid profile between controlled and uncontrolled diabetic subjects. Bangladesh J Pathol 2010;25:10-13 